\title{
Transformational Educational Leadership and the Innovative Strategies Engaging Online Faculty for the Excellent Teaching Performance in the United States
}

http://doi.org/10.21272/bel.5(1).6-21.2021

\section{Lorraine Matos,}

$\mathrm{PhD}$, Management Professor, Lake Mary, FL, USA

Karina Kasztelnik, ORCID: https://orcid.org/0000-0002-1090-3700

$\mathrm{PhD}$, MBA, CPA, CTP, Professor of Accounting, Grand Canyon University, Washington DC, USA

\begin{abstract}
This research paper summarizes the arguments and counterarguments within the scientific discussion on the transformational educational leadership and the innovative strategies engaging online faculty for the excellent teaching performance in the United States. There are various leadership traits of academic leadership to assess engagement amongst online adjunct faculty in the online platform of higher education. This research study focuses on the lived experiences of academic leaders to aid online adjunct faculty in trying to increase the sense of inclusion, engagement, and support. Applying the lived experiences of academic leader could retrieve elements within online adjunct faculty so they can have a positive contribution towards the institution. Support is needed to improve engagement, to assist adequate academic leadership. Systematization of the literary sources and approaches for solving the problem the academic leadership indicates that incorporate individualized strategies when the leader recognizes the value online adjunct faculty bring to their institutions. The relevance of this scientific problem decision is that the themes within this article breakdown the vital impact leaders have with their online adjunct faculty. The wide-ranging factors discussed in this article were categorized to demonstrate the critical components that leadership strategies if implemented effectively, could aid in an engagement component and inclusion for online adjunct faculty. Factors that are vital for academic leadership could be the use of leadership strategies to promote engagement and inclusion within the online environment outlined in this scientific article. The research paper presents the results of an empirical analysis all strategies incorporated in finding the material, history of online education, remote learning environment, leadership traits, leadership support for remote, adjunct faculty, leadership characteristic inactive online adjunct faculty engagement, leadership challenges, authentic relationship, benefits of engagement, communication obstacles on the virtual platforms, and theories within leadership presented a more in-depth understanding on the topic of online adjunct faculty engagement and inclusion. The results of the research can be useful by all academic leaders from all undergraduate, graduate, post-graduate level around the world.
\end{abstract}

Keywords: Leadership, Ethics, Innovation, Strategies, Online Teaching.

JEL Classification: C41, M14, F23, O31, P36.

Cite as: Matos, L., Kasztelnik, K. (2021). Transformational Educational Leadership and the Innovative Strategies Engaging Online Faculty for the Excellent Teaching Performance in the United States. Business Ethics and Leadership, 5(1), 6-21. http://doi.org/10.21272/bel.5(1).6-21.2021.

Received: 02 January 2021

Accepted: 01 February 2021

Published: 30 March 2021

Copyright: (C) 2021 by the author. Licensee Sumy State University, Ukraine. This article is an open access article distributed under the terms and conditions of the Creative Commons Attribution (CC BY) license (https://creativecommons.org/licenses/by/4.0/).

\section{Introduction}

Online adjunct faculty are pertinent to higher education. With the prevalence of technology, the structure of higher education has shifted with more classes being offered in online platforms (Barnett, 2018). The expansion of online courses within the higher education platform aids in providing an influx of positions for online, part-time adjunct faculty to fill in the instructional gap (Barnett, 2018). The general management problem is academic leaders are being challenged to provide the support needed to ensure inclusion of adjunct faculty in an online learning environment (Billot et al., 2013; Thirolf, 2017). Thirolf mentioned that there are various components of leadership characteristics essential to foster a successful relationship between academic leadership and OAF harnessing passionate and dedicated professional. Academic leaders defined in this study 
are individuals "who have the power and resources to affect the teaching mission of the program: these could include program leaders/coordinators, heads of departments/schools, or senior administrators" (Billot et al., 2013: 95). Employee engagement is one of the elements vital for the success of higher education. The problem of this study is to discover leadership strategies to increase inclusion and engagement amongst online, parttime faculty at public colleges in Central Florida. The specific management problem is the lack of engagement amongst part-time, online faculty at community colleges (Pons, Burnett, Williams, \& Paredes, 2017). Within this study we used the definition of engagement derived from Saks. Saks referred to engagement as not being an attitude, rather a specific level that an individual embrace when they are attentive and absorbed in a particular performance in their role (as cited in Anthony-McMann et al., 2017). Engaged employees are more loyal, provide a transformation that revolutionizes the organization, perform better, and are more productive (Raina \& Khatri, 2015). Jolley et al. (2014) emphasized the importance of monitoring and providing support to adjunct faculty amongst institutions. The research problem for this study was the lack of knowledge and research on leadership strategies that aid academic leadership in providing the support needed to ensure inclusion and engagement of adjunct faculty in the online higher education environment within higher education.

The purpose of this study was to discover leadership strategies to increase inclusion and engagement amongst online, part-time faculty at public colleges in Central Florida. The strategies obtained from this study may assist virtual, part-time instructors with a sense of inclusion and engagement. The example of a good leadership is the study in the international corporate financial transfer pricing decision (Kasztelnik, 2020). The increase in number of remote, adjunct faculty throughout the years in online education has changed the higher education platform for institutions. According to Billot et al. (2013) and Thirolf (2017), academic leadership in higher education is challenged to provide the support needed to ensure inclusion to remote, part-time faculty hired to instruct in the online platform. The increase in online courses has, in turn, increased the need for positions available for online instructors to fill in the gap (Barnett, 2018). Along with the growth of online employees, challenges arise for the academic leader in supporting the part-time instructor in staying connected with the institution and engaged within their position. The complexity of leadership in higher education has increased throughout the years with the multifaceted elements that involve online education.

In this article, we start with the literature search strategy that assisted in identifying the resources used to compose the literature review. The second section addresses the four leadership theories which I use to construct the conceptual framework we use in the study: servant leadership theory, shared leadership theory, relationship theory, and the leader-member exchange (LMX) theory. The third section describes the state of the literature with the historical trend of the history of online education and the remote learning environment. The fourth section focuses on the use of strategies for effective leadership. In the fifth section, we provide detail of the scholarly research on the leadership support efforts for remote, adjunct faculty. The sixth section incorporates leadership characteristics that researchers indicate to improve effectiveness with engagement amongst online adjunct faculty. Finally, the seventh section pertains to research on the shift within the higher education platform online, and the challenges associated with that shift (Kasztelnik \& Gaines, 2019).

\section{Gap in the Literature}

The competitiveness and unremitting pressures in the higher education platform have changed tremendously through the years for academic leaders aiding their online adjunct faculty. To assist in remote, employee engagement, academic leadership can start creating a sense of commitment that supports their online adjunct faculty. Ferencz (2017) found that academic leadership can work on connecting with their online adjunct faculty through engagement measures to assist the online adjunct faculty feeling connected to their workplace. Ferencz conducted transcendental phenomenology research to capture the lived experiences of online adjunct faculty with an increased sense of community. According to Ferencz's research, the importance of leadership role to initiate the communication aspect of bringing the sense of community within their online adjunct faculty. Ferencz selected 21 online adjunct faculty from nine institutions to answer a questionnaire. Ferencz found the research data that emphasized the importance of using the different forms of engagement to implement connections needed online. Ferencz stressed that the connections employees make with each other result in the feeling of loyalty to the institution and pride.

The data collected by Ferencz demonstrated how participants in the study were in unison with their responses. Responses from the questionnaire reflected that engagement is essential, although there are various ways that an online instructor can engage themselves. In the remote learning platform, a vital factor for academic leadership is that the faculty is motivated and satisfied, which places more responsibility on the academic leader. Leadership connection becomes different in the online environment rather than a face-to-face 
environment, making it more essential and vital for academic leadership to find means of improving engagement. Ferencz's study fills a gap in the literature by communicating how remote, part-time faculty feel a vital component of the academic leadership is to start the connection online, the online adjunct faculty can increase engagement by asking questions and communicating further with colleges and academic leadership.

Pujol-Cols and Lazzaro-Salazar (2018) sought to find the specific elements that contribute to positive work engagement in relation to work-related psychosocial risk factors. One of the work-related psychosocial risk factors presented in the study was the lack of leadership support. Pujol-Cols and Lazzaro-Salazar emphasized there is a challenge for leadership and their scholars due to the stressors within higher education institutions to provide support. Amongst the many results presented by Pujol-Cols and Lazzaro-Salazar found a gap in the literature due to the presentation of psychosocial risk factors attributing to the lack of support for leaders, job satisfaction, and job insecurity. Academic leadership may use their leadership traits to assist in the absence of support. Doing such actions can present job resources needed to meet the job demands due to the increase in remote, part-time faculty. Reneau et al. (2018) had a similar response in the study as Pujol-Cols and LazzaroSalazar (2018) regarding support measures towards scholars within higher education. Reneau et al. found influential factors that can be incorporated into the daily lives of the academic leader to engage online adjunct faculty. Reneau et al.'s study was conducted to attract and retain experienced, highly skilled faculty. Reneau et al. found the data results to demonstrate the factor impacting the engagement of part-time faculty a sense of feeling support in the online environment from the leader at their institution. Reneau et al., presented other components to assist in the online adjunct faculty within the study were training and mentoring for online adjunct faculty. The academic leader must create an online environment prominent to engagement factors. The dependence of online adjunct faculty amongst institutions has forced leadership to incorporate different leadership strategies to aid in the expansion of the instructors' expertise of the field, flexibility, craving of experiences in the real world (Tipple, 2010). Another vital component for campus leaders is to understand how to sustain and increase motivation within adjunct faculty (Pons et al., 2017). Pons et al. (2017) proclaimed that increasing the motivation of adjunct faculty will aid attributing the actions of the instructor to the mission of the institution. Instructors, within their position, must have the tools and support from their leaders to excel in their positions.

\section{Conceptual Framework}

The phenomenon for this study is the sense of disconnect and engagement of online adjunct faculty with academic leadership in higher education. A significant amount of research has focused on the importance of part-time faculty engagement in higher education (Barnett, 2017; Thirolf, 2017) and further research has identified a feeling of disconnect amongst remote, adjunct faculty (Diegel, 2013; Tarr, 2010; Lather \& Jain, 2015; Barnett, 2017). Limitations that arose in the research of this topic were trying to find particular support measures that embed adequate leadership strategies from academic leadership to aid in the decrease of disconnect and increase engagement amongst online adjunct faculty. Theoretical approaches to leadership can further expand the understanding of the importance of academic leadership in aiding in the act of engagement amongst remote, adjunct faculty. For this particular study, we selected four specific theories: the shared leadership theory, servant leadership theory, relationship theory, and LMX theory. Together, these four theories serve as the conceptual framework for this research to aid in exploring the importance of academic leadership in connection with online adjunct faculty engagement and a sense of disconnect. The four concepts found within the four theories are serving ethically, sharing responsibility, connection, and shared respect. The concepts within the theories selected may assist me in understanding individualized leadership traits that increase engagement with online adjunct faculty. We found the relevance in the online artificial intelligence as the technology support in the online adjunct faculty performance discussed by another author (Kasztelnik, 2020).

Hoch (2014) expressed shared leadership theory is an interactive approach to leadership. The selected concepts within the leadership theories can make an impact in the online adjunct faculty engagement and inclusion. According to Pearce, Wassenaar, and Manz (2008), shared leadership theory can become influential for a leader in using on individuals to achieve an objective. Pearce et al. explained the academic leader who utilizes the shared leadership theory as one who promotes power and influence factors with their managed team. Pearce et al. described the leader using the shared leadership theory further assists their online adjunct faculty in making the appropriate changes between the leader and online adjunct faculty relationship. Improving the relationship between the academic leader and the online adjunct faculty may aid in increasing engagement. Servant leadership theory was introduced to encompass the notion of the leader serving their subordinates. Servant-oriented behaviors demonstrated by a leader consists of empowering other individuals, serving other individuals, and making a difference in the life of other individuals (Flynn et al., 2016). Flynn et al. explained 
how positive factors surrounding the implementation of servant leadership consist of increasing communication measures on behalf of the leaders, helping in understanding the goals and specific tasks set before the company, and focusing on the strength of the employees. Flynn et al. further added that studies concentrated on the servant leadership theory present outcomes of engagement of the employee, job satisfaction, and lower turnover.

Founded on religious teachings, servant leadership emphasizes the leader to be a servant first (Khan, Khan, and Chaudhry, 2015). Leadership traits embedded in servant leadership could be used to motivate servanthood towards the leaders' actions and enhance adjunct faculty engagement. Parris and Peachey (2013) presented the perspective that servant leadership theory has the aspects of ethics, virtues, and morality as the basic constructs to the theory's foundation. Peterlin et al. (2015) mentioned the implementation of servant leadership theory contributes to engagement by supporting followers for success in their positions. Peterlin et al. referred to the servant leadership theory as the well-being of others and underlines to serve the common good. According to Parris and Peachey (2013), particular traits embedded for this specific leadership theory brings humility to a leader by the leader seeking to serve and could make followers feel more valued.

The third and relatively newer theory is the relationship leadership theory. According to Uhl-Bien (2006), relationship leadership theory presents a more human aspect surrounded by the connection for members within the organization. The challenge arises with leadership to build a relationship with faculty members that work remotely. Uhl-Bien explained that the incorporation of relationship leadership theory results in employees being more considerate and supportive. Relationship building in leadership improves helps advancement in engagement and making faculty feel connected. Erdogan and Bauer (2015) presented a different perspective of the LMX theory that includes elements of trust, mutual respect, loyalty, and the quality of the LMX theory. The authors' described what it is, best practices of LMX theory, and how LMX theory is measured. The assumption of the LMX theory is the influential component leaders have within their groups or peers. Erdogan and Bauer pointed out that managers' communicative efforts of support to individuals entering the group; the employee feels more off a sense of trust within the LMX theory. The currency of the LMX theory is essential for employee performance measures, with employees, demonstrating an increase in LMX also exhibit desirable behaviors.

According to Holliday, Martin, and Martin (2010), empirical evidence demonstrated the severe differences amongst groups such as identical temperament, one letter, and no letter in common to place focus on the LMX, respect professionally, and the contribution. This LMX theory shoes the importance of leadership and the relationship with their subordinates connected to LMX theory. In addition, Breevaart, Bakker, Demerouti, and Hetland (2012) conducted a study incorporating leader-member exchange theory (LMX) with job performance. The result of leadership using LMX theory in their daily functions with employees is the enhancement of work engagement. Breevaart et al. argued how engaged employees have an increased sense of enthusiasm, energy, and are satisfied with their work outcome. According to Breevaart et al., employees that have an increase of LMX theory within their relationships as a leader are more resourceful in their work environment, which trickles down to their work engagement.

\section{State of Literature}

Public higher education tries to collapse the limitations of receiving knowledge by expanding online education. To meet the demands of higher education, institutions increase their employee pool to include contingent faculty. This contingent workforce includes full-time, part-time, and non-tenure-track faculty (Jolley et al., 2014). The Coalition on the Academic Workforce (2012) determined that $75.5 \%$ of faculty in higher education institutions classified as contingent faculty. Magda et al. (2015) expressed that among the $75.5 \%$ of contingent faculty, $70 \%$ tend to be part-time or adjunct faculty. According to Magda et al. noted the rapid growth of remote adjunct faculty reported a universal trend amongst higher education institutions. For example, in 2015, 56\% of adjunct faculty instructed in their online platform. In 2011, the National Center for Education Statistics report, found that community colleges are exceeding employing 70\% of adjunct faculty (as cited in Jolley et al., 2014).

The online adjunct faculty growth trend has changed the higher education platform in past years. Online adjunct faculty are being used to teach online courses from various disciplines due to the growth of student enrollment within online higher education. There has been an increasing trend in contingent faculty, which has occurred between 2002 and 2015, with a slight decline after 2011 (Schieffer, 2016). The long-term growth in the increase of online adjunct faculty has advanced more in universities, although colleges have not fallen behind. Various definitions are presented in the literature regarding online adjunct faculty. Due to this study, the definition given is provided by Reneau, Wallace, Claywell, Price, Burdi, and Trybulski (2018), who define 
online adjunct faculty as those individuals who are contracted working per term as needed for the program. Similarly, Magda et al., Jolley et al., Schieffer (2016), and Reneau et al. (2018) are in unison with the increasing trend of online adjunct faculty. The data retrieved from these studies become a vital source for academic leadership to place focus on their growing quantity of online employees to present means of support to engage and include the employees in the online environment.

History of Online Education. The landscape of online education has transformed higher education with institutions focusing on distance education. Definitions of distance education differ throughout the literature (Ferencz, 2017; Magda et al., 2015). Magda et al. presented the description of distance education from the Babson Research Group, which is used for this study. Babson Research Group defined online learning as courses that are $80 \%$ or greater taught online. The change in the higher educational landscape should be embraced by the academic leader to promote engagement, which may aid in institutional growth, diminishing remote, adjunct faculty disconnect, and online adjunct faculty engagement. Ferencz recommended the term "distance education" refers to various types of alternative education, from satellite campuses to virtual learning. Although the definitions of distance education come from two different sources (Magda et al., 2015 \& Ferencz, 2017), the increase in online adjunct faculty demonstrates the importance of focusing on the growth of the online educational instructors to possibly assist them in supporting due to their distance from the institution physically.

Academic leaders within higher education could further utilize the advances of distance education in the online educational platform to incorporate leadership traits to assess the effect of engagement with their remote, parttime faculty. Magda et al. (2015) wrote that higher education remote, part-time instructors are vital to the growth of distance education in universities and colleges worldwide. Incorporating technology in the higher educational platform presents challenges for academic leaders to implement leadership traits that will aid in engaging their online adjunct faculty within distance education. There are various challenges reflected in the literature faced by the online adjunct faculty and academic leadership relationship. The collaboration was the main focus of the study of Schieffer, to understand further how to aid in an increase in engagement and decrease in isolation by academic leadership. According to Schieffer (2016), amongst the many forms of collaboration, an increase in collaboration could be derived from the incorporation of e-mails, discussions, and weekly reflections. Schieffer found within the research that barriers for virtual collaboration could be time constraints of adjunct faculty and trust. Schieffer studied the lived experiences of the online adjunct faculty within a phenomenological qualitative study. Schieffer presented in a study a particular challenge of isolation prone to online adjunct faculty. Schieffer emphasizes that online adjunct faculty fill courses of online courses with little knowledge of how they must collaborate to stay engaged with their peers. Prior study shows that the importance knowledge the international revenue recognition is very crucial in the transformation leadership in education (Kasztelnik, 2015).

The distance incorporated in the online learning environment might be an aspect that encompasses the sense of feeling isolated. According to Schieffer (2016), collaboration becomes easily accessible for adjunct faculty that are on campus, compared to remote, adjunct faculty. Although virtual collaboration varies throughout literature, the definition of virtual collaboration presented by Schieffer came from Coughlin and Kadjer. Virtual collaboration, according to Coughlin and Kadjer, was incorporating multiple methods to assist in individuals working together, communicate, collect resources, and distribute ideas. While Schieffer's study presented the lived experiences of collaboration with online adjunct faculty. Martin, Wang, and Sadaf (2018) provided a different element of engagement by surveying students enrolled in online courses. There are various avenues to assist in the online adjunct faculty engagement with students in an online learning environment. Martin et al. focused on engagement and mentioned that academic leadership could assist with support measures in the presence, connection, engagement, and education of online adjunct faculty. This study incorporated strategies of facilitation from the faculties' viewpoint. Martin et al. (2018) expressed the prominent role of an online facilitator to design and facilitate online learning. The facilitator's responsibility is to be a guide to expand the knowledge of the students and assist in increasing the skills of the class on the topic (Martin et al., 2018; Goldman \& Schmalz, 2012). To succeed in the engagement aspect of instructing in the online platform, academic leadership can make an impact on their part-time instructors by promoting and implementing leadership traits to assist further in engagement.

Grasping the elements that assist online adjunct faculty to be more effective aids the academic leader in finding tools to support the online instructor in their instructional position. Amongst several factors recovered from the results of student perceptions for the online adjunct faculty were instructor presence, timely response, and constant communication with regular announcements. Online courses can become a bit more complicated in 
comparison with face-to-face classes. The asynchronous aspect of online courses become the challenge that much academic leadership has in providing the support needed for online adjunct faculty engagement. Benton and $\mathrm{Li} \mathrm{(2015)} \mathrm{agreed} \mathrm{with} \mathrm{both} \mathrm{Martin} \mathrm{et} \mathrm{al.} \mathrm{(2018)} \mathrm{and} \mathrm{Schieffer} \mathrm{(2016),} \mathrm{implying} \mathrm{how} \mathrm{communication} \mathrm{is} \mathrm{a}$ fundamental component for online adjunct faculty. Benton and Li expressed keeping online, part-time employees engaged in the various activities of the institution and became essential to increase their experience with their employer. Although being a remote employee presents limitations, Benton and Li presented certain elements to foster inclusion amongst online adjunct faculty. According to Benton and $\mathrm{Li}$, "academic leaders could get to know the adjunct faculty, be available and approachable, encourage professional connection, involve the adjunct, collection several resources for the adjunct faculty, provide and participate in adjunct faculty professional development" (p. 3). Understanding the motivational factors of the online adjunct faculty can aid in the use of leadership traits with the leaders and the online adjunct faculty. These recent studies support the idea that the leadership strategy of communication may be an influential factor in engaging online employees to provide inclusion amongst the institution. Instructors are known to expand the knowledge within their profession, and implementing various elements perceived by students and online adjunct faculty to online engagement can better assist academic leadership in understanding how they can better support the engagement of their online instructor in the online platform at the college.

Leadership Strategies. Embracing and understanding the challenges involved within higher education among academic leadership and their online adjunct employees can promote engagement amongst the leader's remote, adjunct faculty. To assist in adding knowledge in the academic leadership profession in higher education, the purpose of this study is to discover leadership strategies to increase inclusion and engagement amongst online, part-time faculty at public colleges in Central Florida. The primary purpose of this study is to explore the lived experiences of the academic leader's use of leadership strategies to assist virtual, part-time instructors with a sense of inclusion and engagement. Ralph Stogdill (1948), a mid-century theorist, referred to leaders as individuals who do not become leaders without possessing different traits. Stogdill came forth to this outcome observing that no two leaders in various industries have identical leadership traits (Stogdill). Kirkpatrick and Locke emphasized the importance of leadership traits. According to Kirkpatrick and Locke, traits from leaders within their field differ from individuals that are not leaders. Leadership traits for those individuals that are leaders compared to non-leaders can include drive, desire to be a leader, honesty/integrity, self-confidence, ability to think cognitively, and experience of the business (Kirkpatrick \& Locke, 1991). Traits from leaders within their field differ from individuals that are not leaders. Kirkpatrick and Locke referred to leadership traits as a characteristic element which assists leaders to attain specific skills, frame and implement the vision of the organization. The research conducted by Kirkpatrick and Locke reflected various examples of leadership traits of effective leaders, such as the founder of Walmart, that still joins morning meetings at the age of 70 . Also, the leadership strategies can be supported by prior study (Kasztelnik \& Delany, 2020) to show how the natural language process plays the significant role in this process.

Nichols (2016) agreed that leadership traits are a vital component to leaders and do matter in their line of work. Leaders are individuals and created differently, so not all leaders encompass the same leadership traits and are unique in their way. Nichols defined traits when an individual demonstrates patterns of consistencies of thought, emotions, and actions. Nichols mentioned 12 individual leadership traits related to dominance or cooperative as "(helpful, pleasant, supportive, agreeable, cooperative, fair, self-confident, self-assured, goaloriented, ambitious, dominant, and assertive)" (p. 665). The results of the finding from Nichols depicted how past leadership experiences affect the value the individual leader places on leadership traits. The data retrieved from Nichols illustrated that the dominance-related leadership traits diminished with the more experience a single leader contained. The research strategies utilized by Kirkpatrick and Locke reinforced Nichol's findings in which highlighted leadership traits are an essential component for leaders to engage their employees. Limitations of Nichols research become in the conclusions where depicting the more experience an individual obtains the which changes the individual, although the individuals participating in the study had self-reported experiences.

Leadership Support for Remote, Adjunct Faculty. There are various leadership traits of academic leadership to assess engagement amongst online adjunct faculty in the online platform of higher education. This study focuses on the lived experiences of academic leaders to aid online adjunct faculty in trying to increase the sense of inclusion, engagement, and support. Applying the lived experiences of academic leader could retrieve elements within online adjunct faculty so they can have a positive contribution towards the institution. Support is needed to improve engagement, to assist adequate academic leadership. Academic leadership plays a vital role in providing the support needed for efficiency in remote, part-time faculty positions. According to Jones (2011), not all leadership traits are effective with employees. Jones emphasized 
the expectations are from adjunct faculty to assist leadership in providing the support needed from the leader. Jones focused the study on the preferences that adjunct faculty have of their academic leaders. According to the results within the study, adjunct faculty wanted supportive leadership that provided them the resources the adjunct faculty needed to conduct their jobs effectively and efficiently. Jones emphasized results that further depicted that adjunct faculty do not need to feel micromanaged and treated as professionals. Leaders are limited with dispersed adjunct faculty presenting some reasoning why instructors look for other sources for direction. Jones mentioned adjunct faculty felt the need for more academic leadership communication. Instead, the focus was on receiving the resources needed for the instructional position. The theoretical framework provided by Jones was appropriate for this study. The leadership theory presented for this study was leadership theory, contingency theory, and the leadership substitute theory for the research. The author selected eight adjunct faculties for this qualitative study. Patton (2015) emphasized that qualitative inquiry usually has small samples, chosen by purpose. The purposeful sampling made this sample size appropriate for the research and will give this study a rich data foundation.

Pons et al. (2017) conducted a qualitative study with a sample size of 103 part-time instructors. Pons et al. observed the responses of online adjunct faculty comments on the significant factors in their online profession. The purpose of Pons et al.'s study was to get the perspective of online adjunct faculty to retrieve the influential factors for motivation. The findings of the data demonstrated three factors that were essential to the online adjunct faculty instructing in their discipline, the chance to work with their students, and individual satisfaction. Although institutions might struggle financially, academic leadership can demonstrate particular traits, not needing financial backing, which is depicted in the results of Pons et al.'s study. Affordable leadership actions that can utilize online adjunct faculty is the demonstration of the act of caring. Leadership characteristics need no money to impact the engagement for online adjunct faculty within the higher education realm. Understanding the response of the most crucial element of instructing in their discipline, effective support measures from academic leadership with online adjunct faculty could achieve the quality and engagement needed in the online education platform within the college.

Pons et al. (2017) retrieved data from online adjunct faculty, Gehrke and Kezar (2015) focused on information retrieved from academic leadership within higher education. Gehrke and Kezar emphasized how leadership in the online portals of higher education have an impact on support for engagement of remote, part-time faculty. Gehrke and Kezar expressed how adjunct faculty usually lack the support from academic leadership at universities. The study conducted by Gehrke and Kezar focused on deans within higher education and their policies of support for non-tenure-track faculty. Gehrke and Kezar presented supporting policies within the study consisted of mentoring, extending contracts, providing orientation, resources to assist in teaching, material, and support from administration. Gehrke and Kezar mentioned the values of academic leadership profoundly affect the decision-making that leads to supportive measures. Leadership plays a significant impact on the success of engagement within the profession of remote, part-time faculty. The sample size collected by Gehrke and Kezar was 264 consisting of deans and faculty, which was sufficient for data retrieval. Gehrke and Kezar mentioned that mentorship and contracts are possible to support measures that can aid engagement within online adjunct faculty. The limitations of this study can be that this study focused on four-year universities and could, in the future, provide guidance for technical school or two-year colleges.

The use of leadership traits can present support engagement measures in higher education. Eagan, Jaeger, and Grantham (2015) mentioned that the shift in the higher education workforce, from mostly full-time faculty to the majority of part-time faculty, had placed a strain with the support of adjunct faculty. Employing adjunct faculty becomes beneficial to institutions, and the reasons vary per institution. According to Eagan et al., some institutions hire adjunct faculty due to their experiences in their full-time careers with the expectation those experiences transfer into the classroom, while other institutions use part-time faculty for budgetary reasons. The study managed by Eagan et al. referred to two categories of adjunct faculty differing on the different satisfaction levels, "voluntary part-time faculty-those part-timers who choose or prefer to work part-time and involuntary part-time faculty-individuals who teach part-time but would prefer a full-time faculty appointment" (p. 450). Regardless of the category, the remote adjunct faculty fall in, support measures may assist in the engagement of the faculty leadership traits within the online atmosphere. The enhancement of engagement with the online adjunct faculty profession can benefit the institution along with the helping the online adjunct faculty. Acknowledging the changes occurring within higher education and understanding the critical aspect of managing part-time, online instructors is a vital element. Leaders could aid in providing the support adjunct faculty need to stay productive and engaged in their positions in the online college environment. Gehrke and Kezar (2015) went beyond the study of Eagan et al. and examined deans while Eagan et al. focused on responses of adjunct faculty. Both studies depicted different views from distinctive 
viewpoints. Incorporating the importance of relationship-building assists in decreasing harmful components of online adjunct faculty might encounter.

An essential element for leadership is taking the limitations presented to the part-time faculty within their institution and overcoming those limitations. Adjunct faculty are usually offered limited office space and provided little or no clerical support and are presented few or no opportunities for professional development (Caruth \& Caruth, 2013). If the instructor's college has limited space for the remote adjunct faculty to assist their students, the leader should find other alternatives to eliminate that limitation. Removing or making changes of certain restrictions on behalf of the leader will aid the adjunct faculty to perform efficiently in their position. Adjunct instructors instruct a higher percentage of students and need support from their academic leadership. The academic leader must take ownership within the relationship between them and the adjunct faculty to assist in different measures to create a healthy work environment surrounded by support.

Authentic Relationship. An authentic relationship between leaders and their remote, adjunct faculty contains essential elements to engage online adjunct faculty. Savage (2017) used a qualitative interpretive case study approach to focus research on shared governance in the relationship between faculty and administration. Savage defined shared governance as a "set of practices under which college faculty and staff participate in significant decisions concerning the operation of the institution" (p. 56). Savage introduced four cultures within higher education administration, derived from Birnbaum (1979), collegial institutions, bureaucratic institutions, political institutions, and anarchical institutions. Savage acknowledged that shared governance presents the right of faculty to make decisions. Savage expressed how shared governance seen as a vital component in fosters engagement with each other. Savage relates that the involvement of faculty within the institution changes the atmosphere of the college or university. Savage interviewed faculty members in this interpretive case study approach and found a similar element amongst faculty is the trust value within the relationship. Faculty in the data collection mentioned they wanted freedom in teaching, in scholarship, and $80 \%$ responded with communication. The limitations of the study were in the questions presented during the data collection process. The questions focused on the aspect of trust in the relationship between the academic leader and the faculty.

Xiong, Lin, Li, and Wang (2016) presented a similar factor within the study of authentic leadership compared to Savage (2017). Xiong et al. motioned that trust is a component found in authentic leaders. Xiong et al. examined authentic leadership relationships between leaders and their subordinates to understand how the relationship affects the employees' connection to the organization. In conducting the study, the leaders superseding in the results were those leaders that practiced authentic leadership. Xiong et al. mentioned that authentic leaders operated to earn the trust of their employees. Employees that had trust in their leaders also demonstrated an increased commitment level towards their company. Commitment is an essential element to an employee's place of employment for a successful outcome. Xiong et al. (2016) defined trust as an employees' expression of certain feelings and incidents towards other individuals. A crucial element within a relationship to promote trust and commitment towards an organization is the authenticity of leaders. According to Xiong et al., leaders demonstrating authenticity might be an essential component in the reactions of employees in the organizational culture and tone. The element of connection amongst the online adjunct faculty may include the factor of engagement for the online adjunct faculty. Xiong et al. emphasized that the lack of trust within the relationship between the academic leadership and the adjunct faculty could diminish the lack of connection. Trust becomes an essential element that sets the foundation for the online adjunct faculty to establish a relationship and receive motivation and support due to the academic leadership knowledge needed for the adjunct faculty. The limitations of Xiong et al.'s study was just to higher education but an element that applies to all leadership within the educational field.

Transformational Leadership. The connection to an employee's workplace is vital for the individual's success. DeLotell and Cates (2017) mentioned the diminishment of connection for online adjunct faculty reduces engagement and work effectiveness. DeLotell and Cates are amongst various scholars who argued transformational leadership style connects with the relationship variable. DeLotell and Cates focused their study on the commitment to the institution's online adjunct faculty based on the relationship these employees have with their leaders and the department chairs transformational leadership style. DeLotell and Cates acknowledged due to the changes in technology, higher education will make a fundamental shift and will change education strategies. According to DeLotell and Cates, transformational leadership approach seeks to meet the challenges of recruiting, training, and evaluating specific individuals. The survey utilized within the study consisted of a three-part questionnaire given to 560 online adjunct faculty. This qualitative research did present the transformational leadership variable being a prominent factor of a component to build a trusting 
relationship with the higher education leader. We can find in the recent study (Umadia, \& Kasztelnik, 2020) how the transformational leadership can support the global economy with the high efficiency.

Jena, Pradhan, and Panigrahy (2018) noted for leaders to foster engagement amongst remote employees, an increase of trust must occur. Jena et al. referred to employee engagement as a present connection factor to the institution and raises ownership amongst the part-time employees. Jena et al. mentioned that work engagement connects an employee to their organization. Various factors become beneficial with the institution's expansion towards distance education (DE). Jena et al. emphasized the importance of transformational leadership characteristics to increase employee engagement. Within the study Jena et al. demonstrated with data how employees that are engaged demonstrate trust and commitment with the assistance of leaders. The results further emphasized how transformational leadership presented an increase in the relationship between employee engagement and trust on behalf of the employee. Increased engagement amongst remote adjunct faculty can benefit the institution.

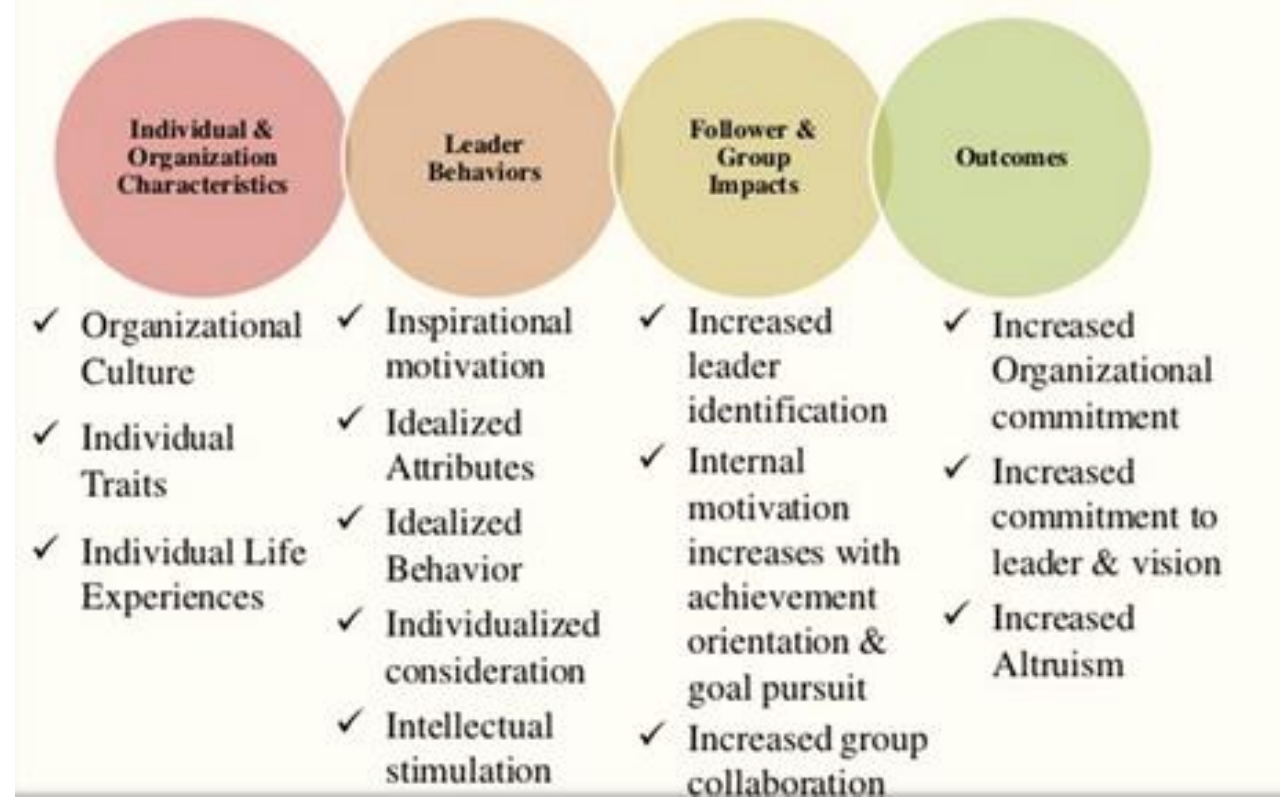

Figure 1. Transformational Leadership

Source: Freddy Guevara

Leadership Characteristic in Effective Online Adjunct Faculty Engagement. Different determinants assist in part-time employee online engagement. The three significant determinant factors of leadership in online adjunct faculty engagement found in the literature review were the inspiration, authenticity, and freedom for adjunct faculty. Anitha (2014) illustrated employee engagement determinants include work environment, team and co-workers, training and career development, compensation, organizational policies, and workplace wellbeing. Anitha referred to a study by Wallace and Trinka, which conducted research demonstrating engagement occurred naturally when leaders inspire their subordinates. This organizational variable becomes essential and difficult when referring to faculty that are not on campus regularly or are on campus at odd hours. Anitha emphasized when leaders communicate to their staff that the individual's work is meaningful and essential to the success of the organization, the leader's result leads to interest and engagement.

Interest and engagement transfer over to a faculty's perception of being part of the institution and can assist in increase employee online engagement. Anitha found a connection between employee engagement and the relationship with leadership. The research indicated a strong relation between an engaged employee and the employee's job performance. Two variables found in the study, enhancing employee engagement, were the work environment and work relationships. For adjunct faculty to partake in the production of the intellectual contribution, the leader's action in inspiration must be evident in their actions and communication strategies. The result abets in the engagement of various attributes of the online adjunct faculties working environment, which consists of instruction, employee development, and communication with academic leadership. Authors believe that the prior study (Delanoy \& Kasztelnik, 2020) showed that the business open big data analytics can support innovative educational process by using the novel technology. Authentic leadership develops from ethical values and stem from leaders genuinely encompassing actions of trustworthy, reliable, and genuine individuals. Gardner, Cogliser, Davis, and Dickens (2011) conducted a literature review of authentic leadership. According to Gardner et al., when a leader embraces authenticity, they provide their personal 
experience, their thoughts, emotions, needs, desires, or beliefs, and their actions surround their self-awareness. The implementation of this type of leadership trait by a leader in academia assist remote, adjunct faculty in feeling support and receiving acceptance. This acceptance ranges from the leader accepting the diversity within their group of remote, adjunct faculty and allowing the different frame of thinking work for the benefit of the department and the college or university.

Boekhorst (2015) conducted an article to focus on the importance of leaders being authentic to bring forth inclusion in the workplace. Boekhorst referred to authentic leadership as bringing inclusion in a workplace environment. Inclusion brings together faculty from different ethnicities, races, and genders to increase the success of department learning goals. Boekhorst pointed out that although adjunct faculty are on campuses part-time, inclusion allows them to feel part of the organization and assist them in striving to accomplish departmental goals. Having a better understanding of the lack of what inauthenticity contains should allow for leaders to aspire in obtaining the characteristic trait of authenticity. Boekhorst emphasized the importance of authentic leaders in regard to diversity to assist their followers in understanding the value of differences in the workplace to incorporate inclusion. Due to the increase in online adjunct faculty in the workplace colleges and universities, embracing authentic leadership assist in the acceptance of various cultures to engage the online adjunct faculty further.

The feeling of inclusion within the remote employee at times can make engagement harder for the academic leader and faculty. Jolley et al. (2014) conducted a qualitative study to research the sense of inclusion amongst the adjunct faculty. Many of the adjunct faculty in the study of Jolley et al. classified themselves as isolated from their institution. Online adjunct faculty were interviewed to understand further. Jolley et al. conducted a study to examine the experiences and challenges of adjunct faculty in their community colleges. Jolley et al.'s investigation resulted in the finding of the lack of engagement amongst adjunct faculty and how the negative views on adjunct faculty assessments. This study depicted how the system is broken within the higher education platform, and leaders can assist. Gardner et al. (2011), Boekhorst (2015), and Jolley et al. focused their research on the leader embodying a different mindset or authenticity. The characteristic of authenticity in a leader can promote an online environment of engagement, inclusion, and support needed for the online adjunct faculty to excel in their position within the institution. In reviewing different sources, there are several tips provided by various scholars to assist in overcoming the challenges encompassed in working with remote employees. Stoker (2018) presented ten tips to work with remote employees. Stoker mentioned helping in remote employee engagement the leader should give assigned tasks in detail of the leaders' expectations for the performance. Other tips provided by Stoker to successfully manage the remote employee; distinguish the goals of the company, present the milestones of accomplishments, implement an open relationship with the remote employee, be flexible, and understand the need of the remote employee, follow up with the remote employee regularly, institute growth goals, and celebrate in the success of the remote employee.

Another leadership characteristic benefiting the increase of remote, adjunct faculty engagement emphasizes the leader's ability to facilitate their followers and deter them from partaking in the actions of micromanagement. Dostaler, Robinson, and Tomberlin (2017) mentioned the Association to Advance Collegiate Schools of Business (AACSB) standards state, for employees to receive success in engagement, there are two different balances vitally important to occur, academic participation and professional engagement. Dostaler et al. emphasized effective engagement cannot happen without academic engagement, professional engagement, or when both elements do not interconnect in some efficient way. Dostaler et al. conducted an empirical study to capture data from 142 students. Dostaler et al. examined the connection of a faculty's engagement in the course with the student's engagement in the classroom. Dostaler et al. found faculty that were engaged in the classroom also had students engaged. Assistance to a leader's faculty becomes critical on employee engagement in the advancement of college and university goals. Engagement entails actions on behalf of the remote, adjunct faculty, and the academic leader. Due to the act of active engagement undergoes entire efforts from the individual partaking in the act. In assisting online adjunct faculty engagement and increasing knowledge, instructors are encouraged to become facilitators in the classroom. Leaders can implement this same concept towards their leadership traits. Leaders inspiring their faculty to assist in the expansion of knowledge results in the instructor feeling comfortable in differentiating their lesson but staying consistent with the departmental goals.

The Need and Benefits of Engagement. Academic leadership can affect the engagement of their online academic faculty. An adjunct massive dual labor market could raise the issue on campuses of the lack of employee faculty engagement. The difficulty increases on behalf of the academic leadership to keep online adjunct faculty engaged within the relationship due to various components institutions have placed on leaders 
to cut costs. Colleges employ online adjunct faculty with minimum or no incentives, a decrease in long-term job security, and no office hours. Adkins (2016) referred to a 2015 Gallup poll demonstrating U.S. workers were engaged $32 \%$, not engaged $50.8 \%$, and actively not engaged $17.2 \%$. Disengagement in institutions affects the leader and part-time faculty relationship. Raina and Khatri (2015) conducted an exploratory study to examine engagement factors of faculty in higher education institutions. Raina and Khatri mentioned employees who are engaged demonstrate characteristics of loyalty, present a transformation element that alters the organization, accomplish better results, and are more productive. Raina and Khatri's literature review on the topic of employee engagement presents the importance of faculty engagement, which can range from cognitive engagement to the emotional dimension of engagement. Raina and Khatri mentioned Livingston (2011) found that there is a challenge to engage faculty. The disengagement of online adjunct faculty impact higher education with negative implications on online employee engagement.

Along with Raina and Khatri (2015), Lather and Jain (2015) wrote a study on employee engagement. Lather and Jain examined employee engagement to understand the link of 10 leadership practices to encourage employee engagement. The leadership practices consisted of "connect, career, clarity, convey, congratulate, contribute, control, collaborate, credibility, and confidence" (Lather \& Jain, 2015: 68). The authors emphasized how disengaged employees are costly for companies ranging from $243-270$ billion dollars lost in productivity. Disengaged employees are seen as disconnected in the working environment (Lather \& Jain). The study of Anthony-McMann, Ellinger, Astakhova, and Halbesleben (2017) examined the relationship between workplace stress and an employee's engagement. Anthony-McMann et al. presented positive attributes on employee engagement from "job satisfaction, job performance, profitability, customer satisfaction, and employee retention" (p. 164). Anthony-McMann et al. suggested that elements in the measurements of engagement assist in understanding the various components of the engagement scale that was mentioned by Kahn. Kahn referred to an increase in positive interpersonal relationships are essential to employee engagement (Anthony-McMann, 2017). Positive critical factors in employee engagement depicted in the study of Lather and Jain (2015). Although various factors can encourage the element of engagement for the remote, part-time faculty, academic leaders could implement academic leadership traits that further produces inclusion, engagement, and support.

Thirolf (2017) suggested a faculty engagement framework to aid in faculty engagement. Thirolf created a framework due to an extensive literature review from the scholar. Thirolf established a framework incorporating communication, socialization, and faculty development to aid in online part-time faculty engagement. Thirolf's suggestion was to incorporate these elements within the first months of new faculty employment. Thirolf's research depicted the essential components of engagement and integration in higher education provided a positive outcome in recognition of removing the obstacles for student success. Thirolf reflected in faculty engagement in their specific roles, and when engagement did appropriately, there is dedication, passion, and positive interaction of their students. Thirolf's research emphasized the importance of adjunct faculty due to their instruction of more than half of the students. Adjunct faculty are seen being ignored by their employers, and the author expressed that engagement and integration are vital. The literature review provided a foundation to understand the importance of engagement and integration on a positive outcome of part-time faculty and student success.

Leadership Challenges. A critical essential element within the online platform at colleges is the complex challenges leaders have to engage their online adjunct faculty adequately. Working remote for most online adjunct faculty consists of trying to stay engaged with their institution presenting challenges for their academic leadership to assist in the engagement process. There are different definitions of engagement within the literature, although, within this study, we will use the definition of engagement from Saks. Saks refers to engagement as not being an attitude, preferably a specific level that an individual embraces when they are attentive and absorbed in an exceptional performance in their role (as cited in Anthony-McMann et al., 2017). Davis, Dent, and Wharff (2015) mentioned the complexity of leadership in higher education and how the challenges have increased due to technology and globalization.

Davis et al. referred to mounting demands for accountability had placed leadership in higher education in a position that institutions have to put a focus on these issues. Davis et al. stressed the importance of organizational performance within the study and how leadership systems are thinking leadership assists in motivation. Crawford and Germov (2015) focused on a study to assist in increasing engagement at the University of Newcastle (UON) in Australian University. Crawford and Germov examined diverse workforce approaches for the study to aid in enhancing development in the instructor's career, improving engagement, and growing particular activities within the faculty. Specific leadership traits utilized by academic leadership 
may assist in the challenges within higher education. Crawford and Germov mentioned due to the increase in academic work, the landscape of higher education instructors has changed, and higher education management can no longer take these individuals for granted. Crawford and Germov focused on the conditions of employment for this group of faculties. Crawford and Germov called adjunct faculty casual employees. Disadvantages within casual employees are "job insecurity, lack of career path, low pay, the absence of accrued leave benefits, and working hours are irregular and unsociable" (Crawford \& Germov, 2015: 535). Implementing specific leadership traits from academic leadership may assist in increasing support amongst their remote, part-time instructors.

The interconnection amongst academic leadership and online adjunct faculty in higher education public colleges present challenges. Tipple emphasized maximizing the quality and effectiveness present in higher education institutions. Tipple offers specific information connected to online adjunct faculty and the motivation behind their teaching, experiencing the leadership styles. The leadership styles prominent in the research were transformational leadership style and situational leadership style. According to Tipple, transformational leadership style has demonstrated to be an effective leadership style to assist in the interaction with employees in the online platforms. Tipple suggests academic leadership must focus on what motivates their online adjunct faculty, to engage them in the online working environment further. The academic leadership should further increase the passion, encouragement, simulation, and direct operation (telephone calls and email) of the remote employees (Tipple, 2010). Along with focusing on the leadership styles, the author presents two sections, the workforce, and the online systems. Tipple (2010) communicates that the same online methods utilized for online support for students can also be applicable for the online adjunct faculty support within higher education. Further, Tipple mentioned that the best leadership style is one that fosters the skills of the adjunct faculty and provides motivation. Similarity, Davis et al. (2015), Crawford and Germov (2015), and Tipple agree that there are new challenges in the academic leadership within higher education to aid in expanding knowledge in the field.

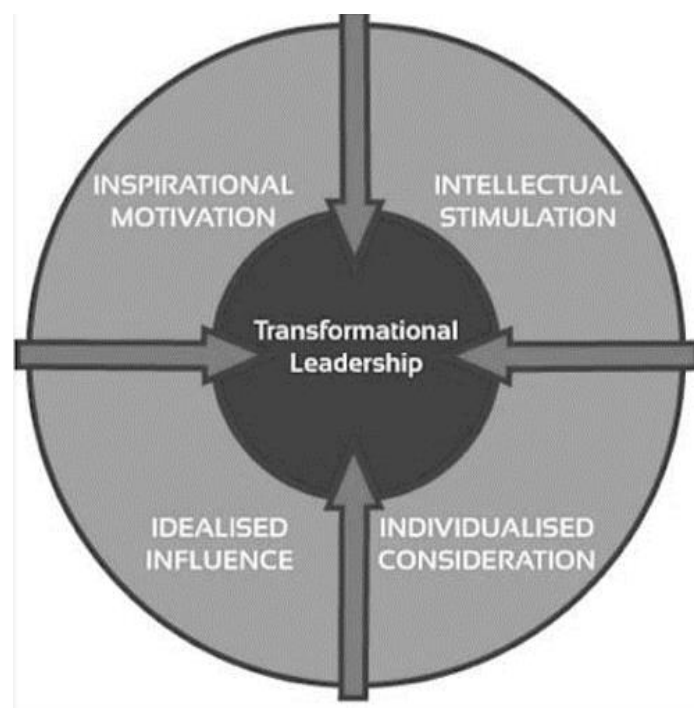

Figure 2. Leadership

Source: Hitesh Bhasin

Communication Obstacles on Virtual Platforms. Interpersonal communication amongst leadership is an essential element of academic leaderships' use of leadership traits amongst their online adjunct faculty to assess engagement. Calota, Pirvulescu, and Criotoru (2015) argued the vital importance of the element of communication in a management position. Calota et al. mentioned successful managers spend $55-95 \%$ of their time conducting various skills in communication (speaking, listening, reading, and writing). The success of management does lie within keeping the forms of communication open. The virtual platform comes with various challenges to academic leadership and their remote, adjunct faculty. Academic leadership can enhance their online communication with online adjunct faculty through email, online discussions, and weekly updates on the department. Online adjunct faculty are more susceptible to isolation compared to on-campus colleagues. Schieffer (2016) conducted a study focusing on the virtual platform and the barriers online adjunct faculty have. The author stressed the importance of collaboration amongst online adjunct faculty. Schieffer suggested within the study are virtual professional learning communities to bring a social outlet where online adjunct faculty can further develop and expand their knowledge. Academic leadership can incorporate their leadership traits within these particular online communities to increase the engagement of faculty and diminish the sense of disconnect. 
In a traditional face-to-face campus setting, leaders are more apt to communicate more with their adjunct faculty. With the transition of adjunct faculty transitioning to online courses, the challenge in the academic leadership position presents to continue the engagement with remote, adjunct faculty. The essential tasks of management are solving issues and communicating correctly to assist progress in their subordinates' performance. In a recent study, Calota et al. (2015) introduced Henry Mintzberg's three levels of management communication, "interpersonal roles, informational roles, and decision-making roles" (p. 78-79). This study suggests that leadership can aid in engagement by incorporating interpersonal skills into their leadership traits, which will help them be a strong skill and help them inspire others. There are various factors to assist in motivation to online adjunct faculty working on online courses. Part-time faculty in some institutions have limited or no resources and limited or no training, which can affect their efficiency in their work (Pons et al., 2017). The vital element for a leader and instructor relationship is finding the need for the academic leader to assist the instructor in growing within their position. Leaders must find areas to comprehend how to "motivate, compensate, develop, and properly utilize this key human resource" the majority amount of faculty within institutions (Pons et al., 2017: 56).

\section{Summary and Conclusions}

The integration of technology has broken down the limitations of higher education to expand their courses towards online education. To address the demands, institutions have turned their attention on increasing the hiring process for online adjunct faculty. Due to the expansion in distance education amongst institutions, the hiring of adjunct faculty has altered the landscape of higher education. More than half of faculty in higher education are now adjunct faculty to aid in the fluctuation of enrollment. The change of online adjunct faculty in higher education has presented challenges of increasing engagement for those remote employees. The virtual platform in higher education presents challenges in which the use of academic leadership traits could assist. The shift within higher education, provided by online courses, becomes unequivocally clear how vital for academic leaders is to take an active role in incorporating leadership strategies to increase engagement in the online platform. Engagement benefits both the instructor and the institution by increasing the sense of connection and passion. Academic leaders within higher education can effectively manage online adjunct faculty in a way with leadership strategies that can increase engagement for these remote employees. Employee engagement affects the various aspect of a remote employee and becomes a ripple effect on behalf of the instructor and academic leadership. Academic leadership traits used to engage their online adjunct faculty may aid in keeping the faculty committed and motivated towards the institution.

Author Contributions. Conceptualization, Karina Kasztelnik \& Lorraine Matos; data curation, Karina Kasztelnik \& Lorraine Matos; formal analysis, Karina Kasztelnik \& Lorraine Matos; investigation, Karina Kasztelnik \& Lorraine Matos; methodology, Karina Kasztelnik \& Lorraine Matos; project administration, Karina Kasztelnik \& Lorraine Matos; resources, Karina Kasztelnik \& Lorraine Matos; software, Karina Kasztelnik \& Lorraine Matos; supervision, Karina Kasztelnik \& Lorraine Matos; validation, Karina Kasztelnik \& Lorraine Matos; visualization, Karina Kasztelnik \& Lorraine Matos; writing - original draft, Karina Kasztelnik \& Lorraine Matos; writing - review \& editing, Karina Kasztelnik \& Lorraine Matos.

Funding. There is no funding for this research.

\section{References}

1. Allen, N., Grigsby, B., \& Peters, M. L. (2015). Does leadership matter? Examining the relationship among transformational leadership, school climate, and student achievement. International Journal of Educational Leadership Preparation, 10(2), 1-22. Available at: https://files.eric.ed.gov/fulltext/EJ1083099.pdf.

2. Anitha, J. (2014). Determinants of employee engagement and their impact on employee performance. International Journal of Productivity and Performance Management, 63(3), 308-323. https://doi.org/10.1108/IJPPM-01-2013-0008.

3. Anthony-McMann, P. E., Ellinger, A. D., Astakhova, M., \& Halbesleben, J. R. (2017). Exploring different operationalizations of employee engagement and their relationships with workplace stress and burnout. Human Resource Development Quarterly, 28(2), 163-195. https://doi.org/10.1002/hrdq.21276.

4. Barnett, D. (2017). Leadership and job satisfaction: Adjunct faculty at a for-profit university. International Journal of Psychology and Educational Studies, 4(3), 53-63. https://doi.org/10.17220/ijpes.2017.03.006.

5. Barnett, D.E. (2018). Online adjunct faculty: A quantitative examination of the predictive relationship between leadership and job satisfaction. International Journal of Research in Education and Science (IJRES), 4(1), 226-236. https://doi.org/10.21890/ijres.383159. 
6. Benton, S., \& Li, D. (2015). Professional development for online adjunct faculty: The chair's role. The Department Chair, 26(1), 1-3. https://doi.org/10.1002/dch.20072.

7. Billot, J., West, D., Khong, L., Skorobohacz, C., Roxå, T., Murray, S., \& Gayle, B. (2013). Followership in higher education: Academic teachers and their formal leaders. Teaching and Learning Inquiry: The ISSOTL Journal, 1(2), 91-103. https://doi.org/10.2979/teachlearninqu.1.2.91.

8. Birnbaum, R. (2004). The end of shared governance: Looking ahead or looking back. New Directions for Higher Education, 2004(127), 5-22. https://doi.org/10.1002/he.152.

9. Boekhorst, J.A. (2015). The role of authentic leadership in fostering workplace inclusion: A social information processing perspective. Human Resource Management, 54(2), 241-264. https://doi.org/10.1002/hrm.21669.

10.Breevaart, K., Bakker, A.B., Demerouti, E., \& Hetland, J. (2012). The measurement of state work engagement. European Journal of Psychological Assessment. https://doi.org/10.1027/1015-5759/a000111.

11.Calota, G., Pirvulescu, B., \& Criotoru, I. (2015). The importance of the management communication process. Internal Auditing \& Risk Management, 10(1), 77-83. Available at: http://www.nou.univath.ro/files/pdf/Nr_1(37)_2015.pdf\#page=82.

12.Caruth, G.D., \& Caruth, D.L. (2013). Adjunct faculty: Who are these unsung heroes of academe? Current Issues in Education, 16(3). https://doi.org/10.1080/10668926.2012.715265.

13.Crawford, T., \& Germov, J. (2015). Using workforce strategy to address academic casualisation: A university of Newcastle case study. Journal of Higher Education Policy and Management, 37(5), 534-544. https://doi.org/10.1080/1360080X.2015.1079394.

14.Davis, A., Dent, E., \& Wharff, D. (2015). A conceptual model of systems thinking leadership in community colleges. Systemic Practice \& Action Research, 28(4), 333-353. https://doi.org/10.1007/s11213-015-9340-9.

15.Delanoy, N., Kasztelnik, K. (2020). Business Open Big Data Analytics to Support Innovative Leadership Decision in Canada. Business Ethics and Leadership, 4(2), 56-74. http://doi.org/10.21272/bel.4(1).56-74.2020.

16.Dostaler, I., Robinson, M.A., \& Tomberlin, T.J. (2017). A focus on engagement: Defining, measuring, and nurturing a key pillar of AACSB standards. Organization Management Journal (Routledge), 14(1), 45. https://doi.org/10.1080/15416518.2017.1293427.

17.Eagan, M.K., Jaeger, A.J., \& Grantham, A. (2015). Supporting the academic majority: Policies and practices related to part-time faculty's job satisfaction. The Journal of Higher Education, 86(3), 448-481. https://doi.org/10.1353/jhe.2015.0012.

18.Erdogan, B., \& Bauer, T.N. (2015). Leader-member exchange theory. International Encyclopedia of the Social \& Behavioral Sciences, 13(2). 641-647. https://doi.org/10.1016/B978-0-08-097086-8.22010-2.

19.Ferencz, T.L.S. (2017). Shared perceptions of online adjunct faculty in the united states who have a high sense of community. Journal of Educators Online, 14(2), 55-73. Available at: https://files.eric.ed.gov/fulltext/EJ1150582.pdf.

20.Field, S.C., Lauzon, L.L., \& Meldrum, J.T. (2016). A Phenomenology of Outdoor Education Leader Experiences. Journal of Experiential Education, 39(1), 31-44. https://doi.org/10.1177/1053825915609950.

21.Flynn, C.B., Smither, J.W., \& Walker, A.G. (2016). Exploring the relationship between leaders' core selfevaluations and subordinates' perceptions of servant leadership: A field study. Journal of Leadership \& Organizational Studies, 23(3), 260-271. https://doi.org/10.1177/1548051815621257.

22.Gardner, W.L., Cogliser, C.C., Davis, K.M., \& Dickens, M.P. (2011). Authentic leadership: A review of the literature and research agenda. The Leadership Quarterly, 22(6), 1120-1145. https://doi.org/10.1016/j.leaqua.2011.09.007.

23.Gehrke, S.J., \& Kezar, A. (2015). Supporting non-tenure-track faculty at 4-year colleges and universities: A national study of deans' values and decisions. Educational Policy, 29(6), 926-960. https://doi.org/10.1177/0895904814531651.

24.Goldman, K.D., \& Schmalz, K.J. (2012). Adjunct teaching: Part-time professorial possibilities, provisions, and provisos. Health Promotion Practice, 13(3), 301-307. https://doi.org/10.1177/1524839912442516.

25.Hoch, J.E. (2014). Shared leadership, diversity, and information sharing in teams. Journal of Managerial Psychology, 29(5), 541-564. https://doi.org/10.1108/JMP-02-2012-0053.

26.Holliday, T., Martin, M., \& Martin, D. (2010). Community college supervisors and their subordinates: A quantitative investigation of personality temperament and leader-member exchange. Journal of Leadership Studies, 4(2), 30-39. https://doi.org/10.1002/jls.20166.

27.Jena, L.K., Pradhan, S., \& Panigrahy, N.P. (2018). Pursuit of organisational trust: Role of employee engagement, psychological well-being and transformational leadership. Asia Pacific Management Review, 23(3), 227-234. https://doi.org/10.1016/j.apmrv.2017.11.001. 
28.Jolley, M.R., Cross, E., \& Bryant, M. (2014). A critical challenge: The engagement and assessment of contingent, part-time adjunct faculty professors in United States community colleges. Community College Journal of Research and Practice, 38(2-3), 218-230. https://doi.org/10.1080/10668926.2014.851969.

29.Kasztelnik, K. \& Delany, N. (2020). Data Analytics and Social Media as the Innovative Business Decision Model with Natural Language Processing. Journal of Business and Accounting, 13(1). Available at: http://asbbs.org/files/2020/JBA Vol 13.1 Fall 2020.pdf.

30.Kasztelnik, K. (2020). Causal-Comparative Macroeconomic Behavioral Study: International Corporate Financial Transfer Pricing in the United States. Financial Markets, Institutions and Risks, 4(1), 60-75. http://doi.org/10.21272/fmir.4(1).60-75.2020.

31.Kasztelnik, K. (2020). Innovative Empirical Model for Predicting National Bank's Financial Failure with Artificial Intelligence Subset Data Analysis in the United States. Open Economics, 3, 98-111. https://doi.org/10.1515/openec-2020-0106.

32.Kasztelnik, K. (2015). The Value Relevance of Revenue Recognition under International Financial Reporting Standards. Journal of Accounting and Finance Research, 4(3), 88-98 http://dx.doi.org/10.5430/afr.v4n3p88.

33.Kasztelnik, K. Gaines, V.W. (2019). Correlational Study: Internal Auditing and Management Control Environment Innovation within Public Sector in the United States. Financial Markets, Institutions and Risks, 3(4), 5-15. http://doi.org/10.21272/fmir.3(4).5-15.2019.

34.Khan, K.E., Khan, S.E., \& Chaudhry, A.G. (2015). Impact of servant leadership on workplace spirituality: Moderating role of involvement culture. Pakistan Journal of Science, 67(1), 109. Available at: https://www.researchgate.net/profile/Dr Abid Chaudhry/publication/277667932 IMPACT OF SERVA NT LEADERSHIP ON WORKPLACE SPIRITUALITY MODERATING ROLE OF INVOLVEME NT_CULTURE/links/556ffb1e08aeccd777417036.pdf.

35.Lather, A.S., \& Jain, V.K. (2015). Ten c's leadership practices impacting employee engagement: A study of hotel and tourism industry. Vilakshan: The XIMB Journal of Management, 12(2), 59-74. https://doi.org/10.1504/IJICBM.2016.076818.

36.Magda, A.J., Poulin, R., \& Clinefelter, D.L. (2015). Online adjunct faculty. Available at: http://www.learninghouse.com/wp-content/uploads/2017/09/Online-Adjunct-Faculty-Report-2015.pdf.

37.Martin, F., Wang, C., \& Sadaf, A. (2018). Student perception of helpfulness of facilitation strategies that enhance instructor presence, connectedness, engagement and learning in online courses. The Internet and Higher Education, 37, 52-65. https://doi.org/10.1016/j.heduc.2018.01.003.

38.Martins, D.C. (2008). Experiences of homeless people in the health care delivery system: a descriptive phenomenological study. Public Health Nursing, 25(5), 420-430. https://doi.org/10.1111/j.15251446.2008.00726.x.

39.Nichols, A. (2016). What do people desire in their leaders? The effect of leadership experience on desired leadership traits. Leadership \& Organization Development Journal, 37(5), 658-671. https://doi.org/10.1108/LODJ-09-2014-0182.

40.Patton, M.Q. (2015). Qualitative Research and Evaluation Methods: Integrating Theory and Practice (4th Ed.). Thousand Oaks, CA: Sage Publications. Available at: https://us.sagepub.com/en-us/nam/qualitativeresearch-evaluation-methods/book232962\#description.

41.Pearce, C.L., Wassenaar, C.L., \& Manz, C.C. (2014). Is shared leadership the key to responsible leadership. Academy of Management Perspectives, 28(3), 275-288. https://doi.org/10.5465/amp.2014.0017.

42.Peterlin, J., Pearse, N.J., \& Dimovski, V. (2015). Strategic decision making for organizational sustainability: The implications of servant leadership and sustainable leadership approaches. Economic \& Business Review, 17(3). https://doi.org/10.15458/85451.4.

43.Pons, P.E., Burnett, D.D., Williams, M. R., \& Paredes, T.M. (2017). Why do they do it? A case study of factors influencing part-time faculty to seek employment at a community college. Community College Enterprise, 23(1), 43-59. Available at: https://digitalcommons.odu.edu/efl fac pubs/35.

44.Pujol-Cols, L.J., \& Lazzaro-Salazar, M. (2018). Psychosocial risks and job satisfaction in Argentinian scholars: Exploring the moderating role of work engagement. Journal of Work and Organizational Psychology. https://doi.org/10.5093/jwop2018a17.

45.Raina, K., \& Khatri, P. (2015). Faculty engagement in higher education: Prospects and areas of research. On the Horizon, 23(4), 285-308. https://doi.org/10.1108/OTH-03-2015-0011.

46.Reneau, M., Wallace, C., Claywell, L., Price, J., Burdi, M., \& Trybulski, J. (2018). Factors influencing part-time faculty engagement with online nursing programs. Nurse Educator, 43(6), 297-301. https://doi.org/10.1097/NNE.0000000000000517. 
47.Robinson, O. (2014). Sampling in Interview-Based Qualitative Research: A Theoretical and Practical Guide. Qualitative Research in Psychology, 11(1), 25-41. https://doi.org/10.1080/14780887.2013.801543.

48.Rubin, H.J., \& Rubin, I.S. (2012). Qualitative interviewing: The art of hearing data (3rd ed., p. 265). Thousand Oaks, CA: Sage Publications. Available at: https://searchworks.stanford.edu/view/11731919.

49.Savage, J. (2017). Determining faculty climate and relationship between faculty and administration. Workplace: A Journal for Academic Labor, 29. Available at: http://ices.library.ubc.ca/index.php/workplace/article/view/186197/185454.

50.Schieffer, L. (2016). The benefits and barriers of virtual collaboration among online adjuncts. Journal of Instructional Research, 5, 109-125. https://doi.org/10.15640/jehd.v4n1a1.

51.Shah, S.S., Shah, A.A., \& Pathan, S.K. (2017). The relationship of perceived leadership styles of department heads to job satisfaction and job performance of faculty members. Journal of Business Strategies, 11(2), 35-56. https://www.researchgate.net.

52.Stogdill, R.M. (1948). Personal factors associated with leadership: A survey of the literature. The Journal of Psychology, 25(1), 35-71. https://doi.org/10.1080/00223980.1948.9917362.

53.Thirolf, K.Q. (2017). Reconceptualizing a more inclusive faculty engagement model: Including and engaging part-time faculty at community colleges. Community College Journal of Research and Practice, 41(4-5), 303-310. https://doi.org/10.1080/10668926.2016.1251357.

54.Uhl-Bien, M. (2006). Relationship leadership theory: Exploring the social processes of leadership and organizing. The Leadership Quarterly, 17, 654-676. https://doi.org/10.1016/j.leaqua.2006.10.007.

55.Umadia, K., \& Kasztelnik, K. (2020). The Financial Innovative Business Strategies of Small to Medium Scale Enterprises in Developing Country and Influence for the Global Economy Performance SocioEconomic Challenges, 4(3), 20-32. https://doi.org/10.21272/sec.4(3).20-32.2020.

56.Xiong, K., Lin, W., Li, J.C., \& Wang, L. (2016). Employee trust in supervisors and affective commitment: The moderating role of authentic leadership. Psychological Reports, 118(3), 829-848. https://doi.org/10.1177/0033294116644370. 